\title{
ANALISIS FAKTOR STRATEGIK MANAJEMEN SUMBER DAYA MANUSIA UNTUK MENINGKATKAN KINERJA KARYAWAN
}

10.34005/akademika.v8i02.499

\author{
Dian Ika Ningrum \\ dianika38@gmail.com \\ Manajemen Universitas Mercubuana \\ Indonesia
}

\author{
Tjiptogoro Dinarjo Soehari \\ tjiptogd@yahoo.com \\ Manajemen Universitas Mercubuana \\ Indonesia
}

\begin{abstract}
Improvement employee performance is very important to support company's business in property industry. Therefore, this research is used as a basic policy to improve employee performance. The methodology in this research is quantitative exploratory method and analyze data used software SPSS for Windows version 24. The variables are Employee Performance $(Y)$ as dependent variable, Work Environment (X1), Competence (X2) and Compensation (X3) as independent variables. This research was conducted at PT Jasamarga Properti with a population of 64 people as saturated samples. All employees are used as samples. (1) Multiple linear regression equation $Y=$ $1.419+0.313 X 1+0.199 X 2+0.187 X 3+e ;$ Rsquare $=0.759, F=59.844$ (2) The work environment is the most dominant factor in Employee Performance; (3) Competence and Compensation have a significant influence on Employee Performance. The results of Employee Performance are 1,419. If $X 1, X 2$ and $X 3$ are considered zero, it will affect employee performance by 1.419 in the Likert scale 1-5. The result is that employee performance is categorized as a very bad category.
\end{abstract}

Keywords: Work environment, Competency, Compensastion and Employee Performance

\begin{abstract}
Abstrak: Peningkatan kinerja karyawan sangat penting untuk mendukung jalannya bisnis perusahaan dibidang properti. Sehingga penelitian ini dijadikan sebagai dasar kebijakan untuk meningkatkan kinerja melalui variabel lingkungan kerja, kompetensi dan kompensasi. Metodologi yang digunakan dalam penelitian ini adalah metode kuantitatif eksploratif dan software SPSS for Windows versi 24. Adapun variabel yang digunakan yaitu Kinerja Karyawan $(\mathrm{Y})$ sebagai variabel dependent sedangkan Lingkungan Kerja (X1), Kompetensi (X2) dan Kompensasi (Y) sebagai variabel independent. Penelitian ini dilakukan di PT Jasamarga Properti dengan populasi sebanyak 64 orang dan menggunakan sampel jenuh. Sehingga seluruh karyawan digunakan sebagai sampel. (1) Persamaan regresi linear berganda $Y=1,419+0,313 X_{1}+0,199 X_{2}+0,187 X_{3}+e$; Rsquare $=0,759, F=59,844$ (2) Lingkungan kerja menjadi faktor paling dominan terhadap Kinerja Karyawan; (3) Kompetensi dan Kompensasi memiliki pengaruh yang signifikan terhadap Kinerja Karyawan. Hasil dari Kinerja Karyawan adalah sebesar 1,419. Apabila X1, X2 dan X3 dianggap nol maka akan mempengaruhi kinerja karyawan sebesar 1,419 dalam skala likert 1-5 termasuk kategori sangat tidak baik.
\end{abstract}

Kata kunci: Lingkungan kerja, Kompetensi, Kompensasi dan kinerja karyawan 


\section{PENDAHULUAN}

Kondisi ekonomi Indonesia yang mengalami perlambatan pertumbuhan akibat kondisi makro ekonomi memberikan dampak negatif terhadap perkembangan properti saat ini. Namun, pada tahun 2016, menjadi awal kebangkitan ekonomi yang mampu menggerakan pertumbuhan di sektor properti sekitar $\pm 3 \%$. Sedangkan pada tahun 2017 pertumbuhan sektor properti meningkat sekitar $\pm 5 \%$, semakin stabil dibanding dengan tahun sebelumnya. Pertumbuhan ekonomi ditambah dengan adanya dukungan pemerintah di sektor properti dengan menyederhanakan peraturan termasuk pengurangan pajak-pajak di sektor properti seperti pajak penghasilan (PPh), Bea Perolehan Atas Hak Tanah dan Bangunan (BPHTB) dan Dana Investasi Real Estate (DIRE). Hal ini memberikan dampak positif bagi perusahaan properti sebagai peluang baru untuk terus tumbuh dan berkembang.

PT Jasamarga Properti (JMP) adalah perusahaan yang bergerak dibidang properti, yang merupakan anak perusahaan dari PT Jasa Marga (Persero) Tbk. Dalam persaingan yang ketat tersebut, diperlukan Sumber Daya Manusia (SDM) yang mampu bekerja tinggi dan mampu menjawab tantangan yang dihadapi oleh perusahaan, untuk itu SDM seharusnya bukanlah beban bagi perusahaan melainkan sebagai asset yang harus terus dikembangkan. Namun, permasalahan pada PT JMP terdapat penurunan kinerja yang terjadi secara fluktuatif selama kurun waktu 3 tahun terakhir.

Berdasarkan data tiga tahun terakhir KPI PT JMP yaitu tahun 2015 pada keuangan dan pasar yang diambil dari pendapatan perusahaan sebesar sebesar 46\%, tahun 2016 sebesar 100,78\% (terjadi peningkatan), tahun 2017 sebesar 54,34\% (terjadi penurunan), pada fokus pelanggan selalu mentargetkan sebesar $100 \%$ setiap tahunnya, pada efektifitas produk dan proses yang diambil dari progress pembangunan proyek, tahun 2015 sebesar 42\%, tahun 2016 sebesar 100,06\% (terjadi peningkatan), tahun 2017 sebesar 50,64\% (terjadi penurunan). Pada fokus tenaga kerja yang diambil dari pemenuhan jumlah kompetensi karyawan, tahun 2015 sebesar 12\%, tahun 2016 4,4\%, tahun 2017 sebesar 1,67\%. Untuk kepemimpinan tata kelola perusahaan selalu mentargetkan $100 \%$ yang diambil dari pengisian Pakta Integritas Perusahaan. Target ini dalam 3 tahun terakhir tidak tercapai sehingga penelitian meningkatkan kinerja karyawan sangat penting. Dalam rangka memperoleh faktor-faktor strategik manajemen sumber daya manusia untuk meningkatkan kinerja karyawan, telah dilakukan pra penelitian menggunakan kuesioner terhadap 25 responden dan Individu Depth Interview (IDI) terhadap 6 responden diperoleh faktor-faktor strategik Lingkungan Kerja, Kompetensi dan Kompensasi yang selanjutnya dijadikan sebagai variabel independent. 


\section{Lingkungan Kerja}

Menurut Sedarmayanti (2011:26), lingkungan kerja adalah keseluruhan alat perkakas, bahan yang dihadapi, lingkungan sekitarnya dimana seseorang belajar, metode kerjanya, serta pengaturan kerjanya baik sebagai perseorangan maupun sebagai kelompok. Kondisi lingkungan kerja dilakukan baik atau sesuai apabila manusia dapat melaksanakan pekerjaannya secara optimal, sehat, aman dan nyaman.

Sedarmayanti (2011:26) menyatakan bahwa secara garis besar, dimensi lingkungan kerja terbagi menjadi dua yaitu: 1) Lingkungan Kerja Fisik, lingkungan kerja fisik adalah semua keadaan yang berbentuk fisik yang terdapat di sekitar tempat kerja yang dapat mempengaruhi karyawan baik secara langsung maupun secara tidak langsung. Lingkungan kerja fisik dapat dibagi dalam dua kategori, yakni: a) Lingkungan yang langsung berhubungan dengan karyawan seperti: pusat kerja, kursi, meja, b) Lingkungan perantara atau lingkungan umum yang dapat juga disebut lingkungan kerja yang mempengaruhi kondisi manusia, 2) Lingkungan Non Fisik, Lingkungan non fisik adalah semua keadaan yang terjadi yang berkaitan dengan lingkungan kerja, baik hubungan dengan atasan, hubungan dengan sesama rekan kerja, ataupun hubungan dengan bawahan.

\section{Kompetensi}

Menurut Spencer dan Spencer dalam Tjutju dan Suwatno (2008:21) menyatakan "a competency is an underlying characteristic of an individual that is casually related to criterion-referenced effective and/or superior performance in a job situation." (Kompetensi adalah sebagai karakteristik yang mendasari seseorang dan berkaitan dengan efektifitas kinerja individu dalam pekerjaannya).

Tjiptogoro (2017) mengemukakan kompetensi adalah kemampuan menerapkan prinsip-prinsip manajemen sumber daya manusia untuk berkontribusi pada keberhasilan bisnis, hubungan manajer antara pelanggan dengan pemangku kepentingan lain sehingga mampu menciptakan layanan yang mendukung keberhasilan organisasi, memberikan nasihat yang tepat kepada karyawan dan pemimpin dalam menghadapi masalah dan solusinya, menjadi inisiatif untuk memberikan aktivitas organisasi secara langsung, memberikan masukan yang efektif, untuk bekerja secara efektif dalam beragam budaya dan latar belakang orang-orang di sekitar lingkungan kerja, untuk menerapkan nilai-nilai dasar integritas, kejujuran dan tanggung jawab, untuk menafsirkan berbagai informasi penting, untuk memberikan rekomendasi yang mempengaruhi keberhasilan tujuan bisnis, untuk memahami fungsi bisnis, organisasi dan industri.

Armstrong (2014:87) dalam Tjiptogoro (2017) mengemukakan bahwa kompetensi merupakan karakteristik yang mendasari seseorang memiliki kinerja efektif atau unggul. Spencer dan Spencer (1993) dalam Sutrisno, Edy (2011:206) terdapat lima dimensi yang digunakan yaitu: 
1) Motif (motives), konsisten berpikir sehingga ia melakukan tindakan. 2) Sifat/Ciri-ciri (traits), watak yang membuat orang untuk berperilaku atau merespons sesuatu dengan cara tertentu. 3) Konsep diri (Self-concept) sikap dan nilai-nilai yang dimiliki seseorang. 4) Pengetahuan (Knowledge), informasi yang dimiliki seseorang untuk bidang tertentu. 5) Kemampuan (Skills), kemampuan untuk melaksanakan suatu tugas tertentu baik secara fisik maupun mental.

\section{Kompensasi}

Menurut Mondy dan Martocchio (2016:374) mengartikan bahwa kompensasi adalah total semua penghargaan yang diberikan oleh perusahaan kepada karyawan sebagai imbalan atas layanan karyawan yang sudah diberikan kepada perusahaan. Tujuan keseluruhan dari kompensasi adalah untuk menarik, mempertahankan, dan memotivasi karyawan. Noe et. Al (2014:341) dikarenakan gaji memiliki efek yang penting terhadap karyawan dan pertimbangan biaya, organisasi harus merencanakan bayaran terhadap karyawan dalam setiap pekerjaan.

Tjipgoro (2017) mengemukakan element-element kompensasi terdiri dari: 1) Kompensasi langsung, a) Gaji, adalah remunerasi dalam bentuk uang yang diterima oleh karyawan sebagai karyawan yang memberikan energi dan pemikiran mereka dalam mencapai tujuan organisasi. Gaji adalah pembayaran tetap oleh karyawan sebagai anggota organisasi. b) dukungan kinerja, adalah dukungan yang diberikan kepada karyawan setiap bulan berdasarkan kriteria kinerja yang ditentukan, c) Insentif, adalah hadiah langsung yang dibayarkan kepada karyawan atas kinerja mereka yang melebihi standar yang ditentukan. Periode waktu insentif dilakukan setelah evaluasi kinerja per semester. 2) Kompensasi tidak langsung: a) Jaminan dan asuransi kesehatan, adalah kompensasi tidak langsung yang diberikan oleh kantor kepada karyawan dalam bentuk program khusus yang menjamin kesehatan atau perawatan karyawan jika mereka sakit atau kecelakaan. b) Pensiun, adalah kompensasi yang diberikan oleh kantor kepada karyawan yang tidak lagi bekerja setelah memasuki akhir masa kerja.

Menurut Mondy dan Martocchio (2016:247) membagi kompensasi kedalam 2 dimensi, yaitu: a) Financial Compesation (Kompensasi Finansial): (1) Kompensasi Finansial langsung, Pembayaran berbentuk uang yang karyawan terima secara langsung dalam bentuk upah, gaji, komisi dan bonus. (2) Kompensasi Finansial Tidak Langsung, Wujud dari kompensasi tidak langsung meliputi keamanan, pesangon, cuti keluarga \& medis, lembur, kesehatan, asuransi jiwa, dana pensiun dan layanan karyawan lainnya: a) Non Finansial Compensation (Kompensasi Non Finansial). (1) The job (kompensasi berkaitan dengan pekerjaan) yaitu dapat berupa pekerjaan yang berarti, penghargaan atas kinerja, pekerjaan yang memuaskan, kesempatan untuk belajar, pekerjaan yang menyenangkan dan menantang. (2) Job environment (kompensasi berkaitan dengan lingkungan pekerjaan). Dapat berupa kebijakan untuk 
berpendapat, atasan cakap, karyawan yang kompeten, rekan kerja yang menyenangkan, dan kondisi kerja yang kondusif. (2) Workplace flexibility (kompensasi berkaitan dengan fleksibilitas tempat kerja). Kompensasi ini dapat berupa waktu yang luang, pekerjaan paruh waktu, minggu tenang dan pembagian kerja.

\section{Kinerja}

Kaswan (2012:212) kinerja merupakan kemampuan karyawan untuk melakukan pekerjaan mungkin ditingkatkan dengan menekankan pada kelebihannya dan pemahaman terhadap perubahan-perubahan apa yang dibutuhkan.

Menurut Collquit et al (2015:32) dalam Tjiptogoro (2017) kinerja adalah nilai kombinasi perilaku karyawan yang memberikan kontribusi positif atau negatif terhadap pencapaian tujuan organisasi.

Mathis dan Jackson (2011:378), kinerja adalah apa yang dilakukan atau tidak dilakukan pegawai yang mempengaruhi seberapa besar banyaknya mereka memberi kontribusi kepada organisasi secara kualitas output, kuantitas output, jangka waktu output, kehadiran di tempat kerja, dan sikap kooperatif.

Bernardin dan Russell dalam Kaswan (2012:187) ada enam dimensi yang dapat dipakai untuk mengukur kinerja, yaitu: 1) Kualitas yaitu seberapa jauh/baik proses atau hasil menjalankan aktivitas mendekati kesempurnaan dan memenuhi tujuan yang dikehendaki oleh suatu aktivitas.2) Kuantitas yaitu jumlah yang dihasilkan. 3) Waktu yaitu seberapa jauh/baik sebuah aktivitas diselesaikan atau hasil yang diproduksi. 4) Efektivitas biaya yaitu seberapa jauh/baik sumber daya organisasi (misalnya manusia, moneter, teknologi, bahan) dimaksimumkan. 5) Kebutuhan untuk supervisi yaitu seberapa jauh/baik seorang karyawan dapat melaksanakan fungsi kerja tanpa harus meminta bantuan pengawasan. 6) Dampak interpersonal yaitu seberapa jauh/baik karyawan meningkatkan harga-diri, itikad baik (goodwill) dan kerjasama antar sesama karyawan dan bawahan.

\section{METODE}

Jenis penelitian ini adalah statistik deskriptif, dengan pendekatan kuantitatif. Penelitian ini dilakukan di PT Jasamarga Properti. Penelitian ini menggunakan metode analisis dengan SPSS versi 24.

Teknik pengambilan sampel dalam penelitian ini menggunakan sampling jenuh dimana semua anggota populasi digunakan sebagai sampel yaitu seluruh karyawan PT Jasamarga Properti dengan jumlah 64 orang.

\section{HASIL}

Dari populasi dan sampel di dapatkan hasil karakteristik responden berdasarkan jenis kelamin laki-laki, yakni laki-laki lebih banyak sebanyak 38 orang $(59,4 \%)$. Berdasarkan usia lebih banyak berusia antara 21-30 
tahun sebanyak 44 orang $(68,8 \%)$. Berdasarkan lama bekerjal Penempatan lebih banyak bekerja kurang dari 1 tahun sebanyak 26 orang $(40,6 \%)$. Berdasarkan pendidikan terakhir lebih banyak berpendidikan D4/S1 yaitu sebanyak 48 orang $(75,0 \%)$. Berdasarkan Jabatan lebih banyak memiliki jabatan staff sebanyak 17 orang $(26,6 \%)$ dan senior officer sebanyak 17 orang (26,6\%).

Uji validitas dilakukan, jika $r$ hitung $>r$ tabel $=0,30$ maka dikatakan valid dengan $\alpha=0,05$. Uji Validitas variabel Lingkungan Kerja $\left(X_{1}\right)$ terdiri dari 19 pernyataan dinyatakan valid, variabel Kompetensi (X2) terdiri dari 14 pernyataan dinyatakan valid, variabel kompensasi $(X 3)$ terdiri dari 11 pernyataan dinyatakan valid dan variabel Kinerja Karyawan (Y) terdiri dari 14 pernyataan, terdapat pernyataan yang tidak valid sebanyak 5 pernyataan sehingga tidak dapat digunakan. Sehingga total penyataan yang digunakan peneliti untuk uji selanjutnya sebanyak 53 pernyataan.

Uji reliabilitas dalam penelitian ini yaitu metode Cronbach's Alpha. Jika $r$ hitung $>r$ tabel $=0,60$ maka kuesioner tersebut reliabel, sedangkan jika sebaliknya maka tidak reliabel. Berdasarkan hasil reliabel Lingkungan Kerja (X1), Kompetensi (X2), Kompensasi (X3) dan Kinerja Karyawan (Y). Yaitu 0,$921 ; 0,920 ; 0,855 ; 0,759>0,60$ sehinga dapat dinyatakan reliabel.

Pengujian normalitas dilakukan jika Uji Kolmogorov-Smirnov Sig $\geq$ 0,05 maka data berdistribusi normal. Jika Uji Kolmogorov-Smirnov Sig < 0,05 maka data berdistribusi tidak normal. Dari hasil uji normalitas lingkungan kerja $(X 1)=0,034<0,05$ dinyatakan tidak normal, Kompetensi $(X 2)=0,200>0,05$ dinyatakan normal, Kompensasi $(X 3)=$ $0,000<0,05$ dinyatakan tidak normal dan Kinerja Karyawan $(Y)=0,200$ $>0,05$ dinyatakan normal. Dengan adanya data yang tidak normal, dilakukan uji Z-score dari ketiga variabel tersebut. Dari hasil tersebut terdapat 3 sampel yang tidak terdistribusi normal, sehingga 3 sampel tersebut tidak digunakan. Sehingga responden yang digunakan sebanyak 61 responden.

Uji asumsi multikolinieritas pengujian Variance Inflation Factor (VIF), jika nilai VIF atas variabel $\mathrm{X}<10$ maka tidak terjadi multikolinieritas. Dari data hasil uji, bahwa VIF $<10$ yaitu Lingkungan Kerja $(X 1)=2,255<$ 10 , Kompetensi $(\mathrm{X} 2)=2,560<10$ dan Kompensasi $(\mathrm{Y})=1,535<10$, maka dikatakan data tidak terjadi multikolinearitas.

Dari data hasil uji Scatter Plot bahwa tidak ada pola yang jelas seperti titik-titik melebar di atas dan dibawah angka 0 pada sumbu $Y$, jadi titik-titik menyebar acak, dan tidak membentuk pola tertentu. Hal ini, bisa disimpulkan bahwa data yang diuji tidak terjadi heteroskedastisitas.

Adapun Analisa Regresi Linier Berganda seperti diperlihatkan dalam tabel 1 berikut : 
Tabel 1. Hasil Analisis Regresi Linier Berganda

\begin{tabular}{|c|c|c|c|c|c|}
\hline \multicolumn{6}{|c|}{ Coefficients $^{a}$} \\
\hline \multirow{2}{*}{ Model } & \multicolumn{2}{|c|}{$\begin{array}{l}\text { Unstandardized } \\
\text { Coefficients }\end{array}$} & \multirow{2}{*}{$\begin{array}{c}\begin{array}{c}\text { Standardized } \\
\text { Coefficients }\end{array} \\
\text { Beta }\end{array}$} & \multirow{2}{*}{$\mathbf{t}$} & \multirow{2}{*}{ Sig. } \\
\hline & B & $\begin{array}{l}\text { Std. } \\
\text { Error }\end{array}$ & & & \\
\hline (Constant) & 1,419 & 0,196 & & 7,221 & 0,000 \\
\hline Lingkungan Kerja & 0,313 & 0,063 & 0,481 & 4,930 & 0,000 \\
\hline Kompetensi & 0,199 & 0,070 & 0,295 & 2,839 & 0,006 \\
\hline Kompensasi & 0,187 & 0,068 & 0,220 & 2,726 & 0,008 \\
\hline
\end{tabular}

a. Dependent Variable: Kinerja Karyawan

Sumber : Hasil Pengolahan Data menggunakan SPSS 24

Diperoleh persamaan regresi sebagai berikut:

$Y=1,419+0,313 X_{1}+0,199 X_{2}+0,187 X_{3}$

1. Konstanta sebesar $\mathrm{a}=1,419$ artinya apabila Lingkungan Kerja (X1), Kompetensi (X2),), dan Kompensasi (X3) dianggap nol (tidak ada) maka Kinerja Karyawan (Y) bernilai 1,419 satuan. Artinya kinerja karyawan termasuk dalam kategori "sangat tidak baik".

2. Variabel Lingkungan Kerja (X1). Memiliki nilai koefisien regresi sebesar $\beta 1=0,313$ artinya variabel Lingkungan Kerja (X1) berpengaruh positif terhadap variabel Kinerja Karyawan ( $Y$ ) serta apabila Kompetensi (X2), dan Kompensasi (X3) dianggap nol (tidak ada atau tidak dilakukan) maka variabel Lingkungan Kerja (X1) akan mempengaruhi variabel Kinerja Karyawan (Y) sebesar 0,313 .

3. Variabel Kompetensi (X2). Memiliki nilai koefisien regresi sebesar $\beta 2=0,199$ artinya variabel Kompetensi (X2) berpengaruh positif terhadap variabel Kinerja (Y) serta apabila Lingkungan Kerja (X1), dan Kompensasi (X3) dianggap nol (tidak ada atau tidak dilakukan) maka variabel Kompetensi (X2) akan mempengaruhi variabel Kinerja Karyawan (Y) sebesar 0,199.

4. Variabel Kompensasi (X3). Memiliki nilai koefisien regresi sebesar $\beta 3=0,187$ artinya variabel Kompensasi (X3) berpengaruh positif terhadap variabel Kinerja $(\mathrm{Y})$ serta apabila Lingkungan Kerja (X1), dan Kompetensi (X2) dianggap nol (tidak ada atau tidak dilakukan) maka variabel Kompensasi (X3) akan mempengaruhi variabel Kinerja Karyawan (Y) sebesar 0,187.

\section{Uji Koefisien Determinasi $\left(\mathbf{R}^{\mathbf{2}}\right)$}

Nilai $R$ Square sebesar 0,759 . Hal ini menunjukkan bahwa variabel lingkungan kerja (X1), kompetensi (X2), dan kompensasi (X3) menjelaskan terhadap variabel kinerja karyawan $(Y)$ sebesar 75,9\%. 
Sedangkan sisanya (100 \% - 75,9 \%) yaitu $24,1 \%$ kinerja karyawan (Y) dijelaskan oleh faktor-faktor lain diluar penelitian ini.

\section{Uji Secara Simultan (Uji F)}

Dari hasil perhitungan, nilai $F$ terlihat $F$ hitung $>F$ tabel bahwa $59,844>2,77$, maka Ho ditolak yang berarti signifikan. Berdasarkan probabilitas hasil analisa diperoleh nilai $0,000<0,05$ berarti Ho ditolak dan Ha diterima. Dapat disimpulkan bahwa Lingkungan Kerja (X1), Kompetensi (X2) dan Kompensasi (X3) secara bersama-sama berpengaruh signifikan terhadap Kinerja Karyawan (Y).

\section{Uji Secara Parsial ( Uji T)}

Uji secara parsial dari setiap komponen persamaan regresi, adalah sebagai berikut:

1. Pengaruh Lingkungan Kerja (X1) terhadap kinerja karyawan adalah signifikan dengan $\mathrm{t}$-hitung $=4,930$ (t-hitung $>\mathrm{t}$ tabel $=$ $2,00247)$ dan nilai Sig. $=0.000$. Nilai coefficient yaitu sebesar 0,313 menunjukkan bahwa arah hubungan antara lingkungan kerja (X1) dengan kinerja karyawan adalah positif.

2. Pengaruh dari Kompetensi (X2) terhadap Kinerja Karyawan (Y) adalah signifikan dengan t-hitung $=2,839$ (t-hitung $>2,00247$ ) dan nilai Sig. $=0.006$. Nilai coefficient yaitu sebesar 0,199 yang menunjukkan bahwa arah hubungan antara kompetensi (X2) dengan kinerja karyawan adalah positif.

3. Pengaruh dari Kompensasi (X3) terhadap Kinerja Karyawan (Y) adalah signifikan dengan t-hitung $=2,726$ (t-hitung $>2,00247$ ) dan nilai Sig. $=0,008$. Nilai coefficient yaitu sebesar 0,187 yang menunjukkan bahwa arah hubungan antara kompensasi (X3) dengan kinerja karyawan adalah positif.

\section{PEMBAHASAN}

1. Nilai konstanta $a=1,419$ menunjukkan kinerja karyawan termasuk ke dalam kategori "sangat tidak baik" sehingga perusahaan perlu melakukan kebijakan dengan meningkatkan lingkungan kerja, kompetensi dan kompensasi.Lingkungan kerja terhadap kinerja karyawan berpengaruh positif dan signifikan dengan nilai koefisien regresi yang terbesar 0,313. Artinya, lingkungan kerja memiliki sensitivitas terbesar terhadap kinerja karyawan sehingga menjadi prioritas pertama perusahaan untuk mengambil kebijakan dalam rangka meningkatkan kinerja karyawan. Pengaruh lingkungan kerja non fisik terhadap kinerja karyawan dalam dimensi kuantitas yaitu karyawan tidak maksimal dalam menyelesaikan pekerjaan sesuai target. Penyebabnya adalah karyawan kehabisan energi dalam menyelesaikan pekerjaan, dikarenakan overload pekerjaan yang ada pada karyawan.

2. Kompetensi terhadap kinerja karyawan berpengaruh positif dan signifikan dengan nilai koefisien regresi terbesar kedua sebesar 0,199. Artinya, kompetensi memiliki sensitivitas terhadap kinerja karyawan 
sehingga menjadi prioritas kedua perusahaan untuk mengambil kebijakan dalam rangka meningkatkan kinerja karyawan. Pengaruh kompetensi terhadap kinerja karyawan dalam dimensi kemampuan menyebabkan menurunnya kualitas kinerja karyawan yaitu karyawan tidak dapat meningkatkan kualitas diri dalam menyelesaikan pekerjaan. Penyebabnya adalah perusahaan tidak memberikan sarana pelatihan secara berkelanjutan karena sistem pelatihan yang belum efektif.

3. Kompensasi terhadap kinerja karyawan berpengaruh positif dan signifikan terhadap kinerja karyawan dengan nilai koefisien regresi terbesar ketiga sebesar 0,187. Artinya, kompensasi memiliki sensitivitas terhadap kinerja karyawan sehingga menjadi prioritas ketiga perusahaan untuk mengambil kebijakan dalam rangka meningkatkan kinerja karyawan. Pengaruh kompensasi non finansial terhadap kinerja karyawan dalam dimensi dampak interpersonal yaitu karyawan tidak dapat mengemukakan ide-ide baru untuk kemajuan Perusahaan. Penyebabnya adalah Perusahaan belum memberikan kompensasi non finansial kepada karyawan dalam pengakuan hasil kinerja. Sehingga karyawan kurang berani mengungkapkan pendapat atau ide baru untuk kemajuan perusahaan.

4. Lingkungan kerja, kompetensi dan kompensasi secara bersama-sama berpengaruh positif dan signifikan terhadap kinerja karyawan dengan $\mathrm{F}$ sebesar 59,844. Artinya jika lingkungan kerja, kompetensi dan kompensasi secara bersama - sama ditingkatkan maka akan meningkatkan kinerja karyawan. Perusahaan belum melakukan secara bersama-sama perbaikan lingkungan kerja, peningkatan kompetensi dan pemenuhan kompensasi untuk meningkatkan kinerja karyawan.

\section{KESIMPULAN DAN SARAN}

\section{Kesimpulan}

Berdasarkan data yang diperoleh dan dianalisis, dapat disimpulkan hal-hal sebagai berikut:1) Untuk meningkatkan kinerja karyawan Perusahaan perlu melakukan kebijakan dengan meningkatkan lingkungan kerja, kompetensi dan kompensasi. 2) Lingkungan kerja (X1) berpengaruh positif dan signifikan terhadap kinerja karyawan (Y) PT Jasamarga Properti. Artinya, lingkungan kerja memiliki sensitivitas terbesar terhadap kinerja karyawan sehingga menjadi prioritas pertama perusahaan untuk mengambil kebijakan dalam rangka meningkatkan kinerja karyawan. 3) Kompetensi (X2) berpengaruh positif dan signifikan terhadap kinerja karyawan (Y) PT Jasamarga Properti. Artinya, kompetensi memiliki sensitivitas terhadap kinerja karyawan sehingga menjadi prioritas kedua perusahaan untuk mengambil kebijakan dalam rangka meningkatkan kinerja karyawan. 4) Kompensasi (X3) berpengaruh positif dan signifikan terhadap kinerja karyawan (Y) PT Jasamarga Properti. Artinya, kompensasi memiliki sensitivitas terhadap kinerja karyawan sehingga 
menjadi prioritas ketiga perusahaan untuk mengambil kebijakan dalam rangka meningkatkan kinerja karyawan, 5) Lingkungan kerja (X1), kompetensi (X2) dan kompensasi (X3) terhadap kinerja karyawan (Y) secara bersama-sama berpengaruh secara signifikan terhadap kinerja karyawan PT Jasamarga Properti. Artinya, jika lingkungan kerja, kompetensi dan kompensasi secara bersama - sama ditingkatkan maka akan meningkatkan kinerja karyawan.

\section{Saran}

Adapun sarannya sebagai berikut: a) Kebijakan perusahaan dalam upaya meningkatkan kinerja karyawan melalui variabel lingkungan kerja dapat dilakukan dengan cara:b) Membuat workload analysis dan melakukan pembagian kerja sesuai dengan job descnya masing-masing sehingga karyawan dapat fokus pada pekerjaannya, tidak membuang energi dalam menyelesaikan, mengurangi kesalahan dan ketidaktelitian, sehingga kuantitas kinerja terpenuhi dan pekerjaan dapat diselesaikan sesuai dengan target yang ditentukan.

a. Membuat Standard Operating Procedures (SOP) kerja yang jelas dan terperinci. Prosedur kerja tersebut dapat mengajarkan kepada karyawan bagaimana cara bekerja dengan baik dan benar agar tidak menimbulkan kebingungan dalam menyelesaikan pekerjaan mereka. Sehingga karyawan dapat menyelesaikan pekerjaan sesuai dengan target yang telah ditentukan;

b. Perusahaan juga harus memperhatikan fasilitas kerja fisik kantor seperti srikulasi udara yang terdiri dari temperatur udara, kelembapan udara dan kebersihan udara.

c. Kebijakan perusahaan dalam upaya meningkatkan kinerja karyawan melalui variabel kompetensi dapat dilakukan dengan cara:

d. Perusahaan memberikan pelatihan dan pengembangan kepada karyawan dalam kurun waktu tertentu;

e. Perusahaan tidak memilih - milih dalam memberikan pelatihan terhadap karyawan seingga pelatihan tersebut bisa didapatkan oleh setiap karyawan. Seperti pelatihan formal dan informal. Untuk pengembangan seperti team building, leadership, corporate culture.

f. Mengembangkan ketrampilan baik dari sisi peningkatan attitude, skill dan knowledgenya yang ditujukan untuk membantu pengembangan dirinya dalam melaksanakan tugas dan tanggung jawab jabatannya sesuai KPI (Key Performance Indicator).

\section{DAFTAR PUSTAKA}


Annual Report PT Jasamarga Properti, (2017).

Dinarjo Soehari Tjiptogoro. (2017). Performance Improvement Through Human Capital Strategic For Civil Servant. International Journal Of Applied Business amd Economic Research. Vol.15 No. 24. Serial Publications Pvt. Ltd.

Kaswan. (2012). Manajemen Sumber Daya Manusia untuk Keunggulan Bersaing Organisasi. Edisi Pertama. Yogyakarta: Graha IImu.

Mathis, Robert L. dan Jackson, John H. (2011). Human Resources Management (edisi 10). Salemba Empat. Jakarta.

Martocchio Joseph J, R. Wayne Mondy.(2016). Human Resource Management. Pearson Education Limited: Global Edition.

Noe, Raymond A. (2014). Fundamentals of Human Resource Management. McGraw-Hill//rwin: New York.

Sedarmayanti, (2011), Manajemen Sumber Daya Manusia, Reformasi Birokrasi dan Manajemen Pegawai Negeri Sipil (cetakan kelima). Bandung: PT Refika Aditama.

Sutrisno, Edy. (2011). Manajemen Sumber Daya Manusia Cetakan Ketiga. Kencana Prenada Media Group. Jakarta.

Tjiptogoro, Djumarno. (2018), The Strategic Role of Management of Human Resources to Prevent Corruption. Vol 3, Number 3, 2018. Journal of Business and Economics Review. Global Academy of Training \& Research (GATR) Enterprice.

Tjiptogoro, Iffah. (2017), Analysis of Strategic Factors of Human Resources Management for Corruption Prevention. Volume 15, Number 6, 2017. International Journal of Applied Business and Economic Research. Serial Publications Pvt. Ltd.

Tjiptogoro, Iffah. (2017), Performance Improvement Through Human Capital Stategic For Civil Sevant. Volume 24, Number 6, 2017. International Journal of Applied Business and Economic Research. Serial Publications Pvt. Ltd.

Tjiptogoro, Iffah, Fransica, Hapzi. (2017), Corruption Prevention and Deterrence Through Strategic Human Resources Management Vol: 6, Issue 1, January 2017. International Journal of Application or Innovation in Engineering \& Management. IJAIEM Index by Thomson Reuter \& Other. 
Tjiptogoro, Iffah, Havidz, Hastuti (2017), Strategic Factors of Human Capital for Employees Performance Improvement Volume 14, Number 13, 2017. International Journal of Economic Research. Serial Publications Pvt. Ltd.

Tjiptogoro, Iffah, Mirza. (2017), Managerial Leadership for Competitive Advantage University. Volume 24, Number 6, 2017. International Journal of Applied Business and Economic Research. Serial Publications Pvt. Ltd.

Tjutju Yuniarsih dan Suwatno, (2008). Manajemen Sumber Daya Manusia Teori,Aplikasi dan Isu Penelitian. Alfabeta. Bandung.

Walton. (1999). Strategic Human Resource Development. Pearson Education Limited. Edinburgh Gate Harlow. England.

Werther and Davis. (2006). Human Resources and Personal Management. International Edition. Mc Graw Hill. Print in Singapure.

Wheelen and Hunger. (2006). Strategic Management and Business Policy. Pearson Education International. United State of America 